\title{
Major Advances in Genetic Evaluation Techniques
}

\author{
R. L. Powell ${ }^{1}$ and H. D. Norman \\ Animal Improvement Programs Laboratory, Agricultural Research Service, USDA, \\ Beltsville, MD 20705-2350
}

\section{ABSTRACT}

The past quarter-century in genetic evaluation of dairy cattle has been marked by evolution in methodology and computer capacity, expansion in the array of evaluated traits, and globalization. Animal models replaced sire and sire-maternal grandsire models and, more recently, application of Bayesian theory has become standard. Individual test-day observations have been used more effectively in estimation of lactation yield or directly as input to evaluation models. Computer speed and storage are less limiting in choosing procedures. The increased capabilities have supported evaluation of additional traits that affect the net profitability of dairy cows. The importance of traits other than yield has increased, in a few cases due to an antagonistic relationship with yield. National evaluations combined internationally provide evaluations for bulls from all participating countries on each of the national scales, facilitating choices from among many more bulls. Selection within countries has increased inbreeding and the use of similar genetics across countries reduces the previously available outcross population. Concern about inbreeding has prompted changes in evaluation methodology and mating practices, and has promoted interest in crossbreeding. In just the past decade, distribution of genetic evaluations has gone from mailed paper or computer tapes for a limited audience to publicly accessible, request-driven distribution via the Internet. Among the distributed information is a choice of economic indices that combine an increasing array of traits into numbers reflecting breeding goals under different milk-pricing conditions. Considerable progress in genomics and the mapping of the bovine genome have identified markers for some deleterious recessive genes, but broader benefits of marker-assisted selection are still in the future. A possible exception is the proprietary use of DNA testing by semen producers to select among potential progeny test bulls. The collection and analysis of industry-wide data to evaluate ge-

Received December 29, 2004.

Accepted January 20, 2005.

${ }^{1}$ Corresponding author: rpowell@aipl.arsusda.gov netic merit will continue to be the most important tool for genetic progress into the foreseeable future.

Key words: genetic evaluation, Interbull, evaluation accuracy, somatic cell score

\section{INTRODUCTION}

In the 75th anniversary issue, it was reported that "genetic parameters have been estimated for most economically important traits." However, evaluations of calving ease (CE), SCS, productive life (PL), and female fertility, information we now take for granted, were not yet available. The authors foresaw the importance of susceptibility to mastitis and correlations among traits "to define economic worth" for use in indices. Longevity and reproductive traits were also cited as important topics for future development. Since that report was published in 1980, changes in genetic evaluation techniques have brought advances in an array of areas. Progeny testing, production recording, and selection indices are aspects addressed in other articles in this issue. Here we deal with models, data sources and adjustments, traits evaluated, and data exchange. Advances in computation are central to genetic evaluation but are not covered in detail. Emphasis is on the United States, but some reference to other national situations and Interbull is also relevant. Changes similar to those in the United States have occurred in other national evaluation systems. Yield evaluation is addressed first as it preceded other traits and many of the considerations for yield apply for the other traits. Further consideration of traits other than yield reflects the recent increase in emphasis given to these traits by industry.

\section{MODELS}

A major change in approaches to genetic evaluations occurred in the 1970s. Selection index methods popularized by Hazel were generally replaced by the mixed model methodology advanced by Henderson. An advantage of the new approach was that for a given model, the results have best linear unbiased prediction (BLUP) properties. Although mixed models are ideal for normally distributed data, alternative models have been developed for traits that are not normally distributed, 
such as generalized linear models, threshold, or survival models. Additionally, applications of Bayes' theorem have permitted advances in modeling and especially (co)variance component estimations.

Beginning in 1974, the modified contemporary comparison (MCC) was used for evaluation of yield by USDA's Animal Improvement Programs Laboratory (AIPL). This procedure incorporated many improvements over the previously used herdmate comparison. The major advantages were: 1) consideration of the merit of herdmates, 2) inclusion of genetic groups based on pedigree index, and 3) improved weighting of information. The MCC was shown to produce bull evaluations essentially identical to those derived using a linear model with BLUP properties when both models included the same fixed and random effects. The MCC was a sire model and was replaced in 1989 with an animal model (AM). Canada also adopted AM in 1989 and by the 1992 report from Interbull on national evaluation systems, AM was the standard method. A key technique used in AM computing is "iteration on the data."

The advantages of the AM were that it considered all relatives, no matter how distant, and all animals of a breed were evaluated simultaneously, male and female. For brevity in this paper, AM refers to the application to lactation records. The test-day model (TDM) is also an animal model but focuses on each test-day observation rather than on lactation data. The TDM, first introduced in Australia in 1984, models each testday observation instead of the lactation record, or preadjusts lactation records for the test-day effect. A TDM allows for a more exact specification and consideration of the environment (a day vs. a lactation). Often, TDM include consideration of persistency of lactation and rate of maturity.

All effective evaluation procedures include fixed or random effects to account for management situations (environment). The more similar the situation within a management group, the better the removal of environmental effects. However, with the MCC and AM, an effort was made to balance between specificity of the environment and the accuracy of estimating the effect of that situation (number of cows). The MCC used a rolling definition of contemporaries, cows in the same parity group (first vs. later) and calving in the same month as the cow of interest or in the 2 preceding or following months. With the implementation of the USDA AM, management groups were defined as cows in the same parity group, calving in a 2-mo period (January-February of a given year and so on), and for Holsteins, having the same registry status (registered or grade). If there are not 5 cows in a management group, requirements are relaxed successively by increasing the calving period by $2 \mathrm{mo}$, combining registry groups, further expanding the calving period, and combining parities; the required group size is reduced to 3 ; and the calving period is further increased incrementally up to $1 \mathrm{yr}$. Records for cows still not having a group-mate are excluded.

Although test-day data have been collected in the United States since 1905 for management and have contributed to national genetic evaluations since 1936, the TDM was patented in the United States in 1993, later in Canada, and a patent was applied for in Europe. This has forestalled its use in the United States except for regional and unofficial evaluations by the patent holder. Many other countries besides Australia have now adopted a TDM [Belgium, Canada, Estonia, Finland, Germany-Austria, Italy (Holstein), The Netherlands, Switzerland, and South Africa (Guernsey and Jersey)].

Recent work has shown that covariance functions can account for changes in (co)variance components over a continuous scale. This capability has been incorporated into repeatability models by using random regressions called random coefficients to account for repeated records. Random regression has been used for longitudinal data such as are found in test-day records. In TDM, this involves representing the test-day yields over the lactation curve with an equation. The equation is typically a regression on Legendre's polynomials of order 3 or higher.

Throughout the 1980s, export of North American semen to several countries became widespread, encouraged by the results of a Food and Agriculture Organization trial comparing 10 strains of Black and White cattle in Poland. Some highly evaluated bulls ended up with large numbers of daughters in several countries. This provided a means to determine bull merit on an international basis.

Beginning in 1994 with 4 Nordic countries and 2 breeds, Sweden-based Interbull (International Bull Evaluation Service) has combined national genetic evaluations across countries and provided evaluations for the combined set of bulls on each participating country's scale. In August 1995, the multiple-trait, acrosscountry evaluation (MACE) system developed by L. R. Schaeffer was adopted, which includes genetic correlations between countries of less than one. Changes made in Interbull procedures over the years include: restriction on maximum bull age (1997), minimum birth year fixed (2004), weighting of data according to nationally calculated effective daughter contribution, enactment of rules for inclusion of imported bulls (2002 and 2004), and estimation of genetic correlations (2004). In 2005, 27 Holstein populations and 47 other breed-country populations in 5 other breeds (Ayrshire, Brown Swiss, 
Guernsey, Jersey, and Simmental) participated in Interbull evaluations for yield.

Increasingly, countries are making use of computer programs and statistical packages developed elsewhere rather than programming their own systems. This is occurring in countries with established evaluation systems as well as in emerging countries. A few countries have joined forces for common evaluations (Austria and Germany, Netherlands and the Flemish part of Belgium, the Nordic countries). These and other efforts are related to the concept of borderless evaluations in which test-day data from many countries are the input and herds with common characteristics, regardless of nationality, share evaluation parameters.

Identification and use of the best bulls nationally and internationally, especially to sire sons, has increased the relationships within breeds with consequent narrowing of the genetic base. This simply means a reduction in the diversity of bloodlines. Thus, nearly every animal is inbred (maybe all, if we tracked pedigrees back a few more generations); that is, at least one ancestor appears on both sides of the animal's pedigree. Inbreeding is the probability that both alleles at a locus came from the same ancestor. The closer the common ancestor, the greater the probability of having identical alleles descended from that same ancestor, and the higher the inbreeding coefficient. Mating of related animals results in inbreeding depression (loss of fitness due to homozygosity of unfavorable recessive genes) in many traits, particularly those for health, but also for productivity. Until the $1980 \mathrm{~s}$, it was suggested that if the problem of the narrowing genetic base in North America became serious, genetic variation could be reinstituted from other world populations. However, even 25 yr ago, global populations were becoming more similar due to incorporation of North American genetics.

Since 1994, AIPL has computed inbreeding on all animals (born since 1960) and accounted for it in constructing the inverse of the relationship matrix. Thus, the greater similarity in genes and reduced variation in performance was considered. For bulls, their own inbreeding and the average inbreeding of their daughters were provided to the industry. In 1998, expected inbreeding of future progeny was provided to identify outcross bulls. In 2005 , bulls were credited with the inbreeding of daughters (that decreased performance) and debited for expected future inbreeding (due to relationship with the current population of potential mates).

The tremendous success of the dairy cattle improvement efforts is seen in Figure 1. Although the size of the national dairy herd has shrunk considerably, total milk production has increased dramatically. This progress represents advances in many areas including ge- netics. For the improved genetic potential to be realized, feed and other management inputs also change to meet the increasing requirements of cows. Although this makes it difficult, if not impossible, to truly partition improvement according to source, a number of studies have credited genetic improvement with a majority of the increase in productivity. Mean genetic merit for milk of Holstein cows increased $113 \mathrm{~kg} / \mathrm{yr}$ from 1988 to 1998 compared with the overall phenotypic trend of $221 \mathrm{~kg} / \mathrm{yr}$. In the most recent years, changing selection emphasis is reflected in a reduction in the genetic trend for milk. A summary of the genetic and phenotypic trends for various traits is updated quarterly and is available at http://aipl.arsusda.gov.

\section{DATA SOURCES}

Some significant changes have occurred in the way dairy records are collected and processed. Increased onfarm use of computers, decentralization of the DHIA, and the trend toward lower cost milk-recording programs have all had an impact on the type of records included in genetic evaluations. About two-thirds (64\%) of US testing is a.m./p.m., which means only one milking is measured monthly, alternating between morning and evening milkings. Another $12 \%$ have only one milking sampled for components. Milk weights recorded by on-farm computers may be averaged over several days and reported in one record, and 5\% of herds participate in DHIA using this "labor-efficient record" test plan. Inclusion and weighting of records is based on the number of milkings weighed and sampled contributing to each test-day record, the number of test days during the lactation, and the supervision used generating each test-day record. Owner-sampler records were included in evaluations beginning in 1997 with reduced weight, and subject to additional requirements, which include completeness of reporting identification and deviation of reported milk from milk actually shipped.

Weighting of records is by data collection rating (DCR), which is the expected data quality based on the record criteria described above. The DCR is a reliable indicator of how closely the estimated lactation yield represents the true lactation yield because it considers the number and spacing of test-day records and the expected correlations between all the reported test days for the lactation. The expected test-day correlations for any 2 test days in a 305-d lactation can be approximated by $0.995^{\mathrm{n}}$, where $\mathrm{n}$ is the interval between test days, although they are slightly lower in earlier lactation than in later lactation. Correlations used in calculation of DCR were calculated in 1998 using test-day records from 500,000 lactations from 1990 to 1996. 


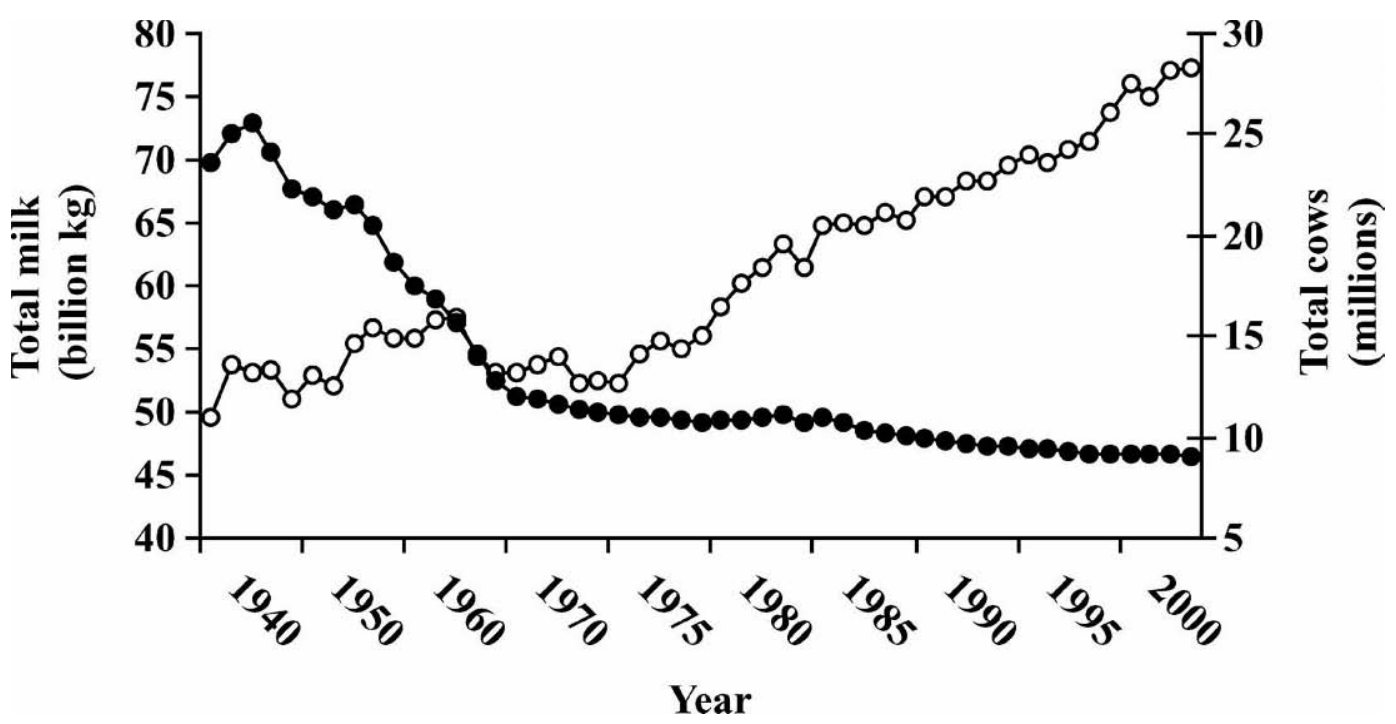

Figure 1. Total milk production $(\bigcirc)$ and number of cows $(\bullet)$ in the United States, by year.

Although fat yield has long been an integral part of the milk recording system, protein was still relatively new in 1980 , with $71 \%$ of cows with usable records and relatively little historical data; in 2005, $97 \%$ of records included protein reporting. In 2000 , the scale for protein was changed from crude protein to true protein, which lowered the percentage by about 0.19 . Crude protein is estimated from nitrogen and includes nonprotein nitrogen, thus overestimating protein content. This change reflected the change to a true protein basis for milk payments in several Federal Milk Marketing Orders.

Rate of accumulation of data on evaluated bulls and cows is shown in Figure 2. Bulls are those having at least 10 evaluated daughters. Although the number of new AI bulls [those with a National Association of Animal Breeders (NAAB) registration code] is slightly higher today than in 1980, the number of non-AI bulls has decreased dramatically. This healthy trend is apparent, even considering that the lower numbers of nonAI bulls in the most recent years reflect the fact that these bulls take longer to accumulate 10 daughters. Numbers for cows are those evaluated for yield, meaning cows on production recording for milk and fat, with valid sire identification, and that passed additional edits for data consistency and quality. Numbers of evaluated cows have declined since their highest level in 1990 but have been constant since 1996 .

Records other than conformation scores are provided to USDA by the Dairy Records Processing Centers (DRPC). Since 1980, the number of DRPC has fallen from 10 to 5 . Conformation records are collected by the classification programs of the breed associations.
Pedigree data are supplied to USDA by the breed associations for registered (or other enrolled) animals, and by the DRPC for others. For animals born in 1980, more than half of all pedigree records came from the breed associations. For animals born since 1986, DRPC production records have been the largest source of pedigree data overall; however, for breeds other than Holstein, most pedigrees still come from the breed associations. Bull pedigrees supplied by Interbull and the NAAB are also incorporated into the USDA database, but these account for only a few (3\%) bulls currently in use in the United States.

\section{DATA ADJUSTMENTS}

The process of genetic evaluation is essentially one of excluding nongenetic effects through precorrection of data or through the model, and properly weighting the remainder. Input data to the MCC and AM are lactation records standardized for age, lactation length, previous days open, frequency of milking, and month of calving. As regional or national populations and management practices change, factors periodically need to be changed. Often, new estimation and implementation strategies are used when the factors are updated.

Genetic evaluations express the relative merit of animals, providing a ranking of animals and an estimate of the magnitude of differences between animals. Evaluations are adjusted so that for a defined base group of animals the average is zero. The United States and many other countries change the base group every 5 yr, as recommended by Interbull. Canada, France, and 


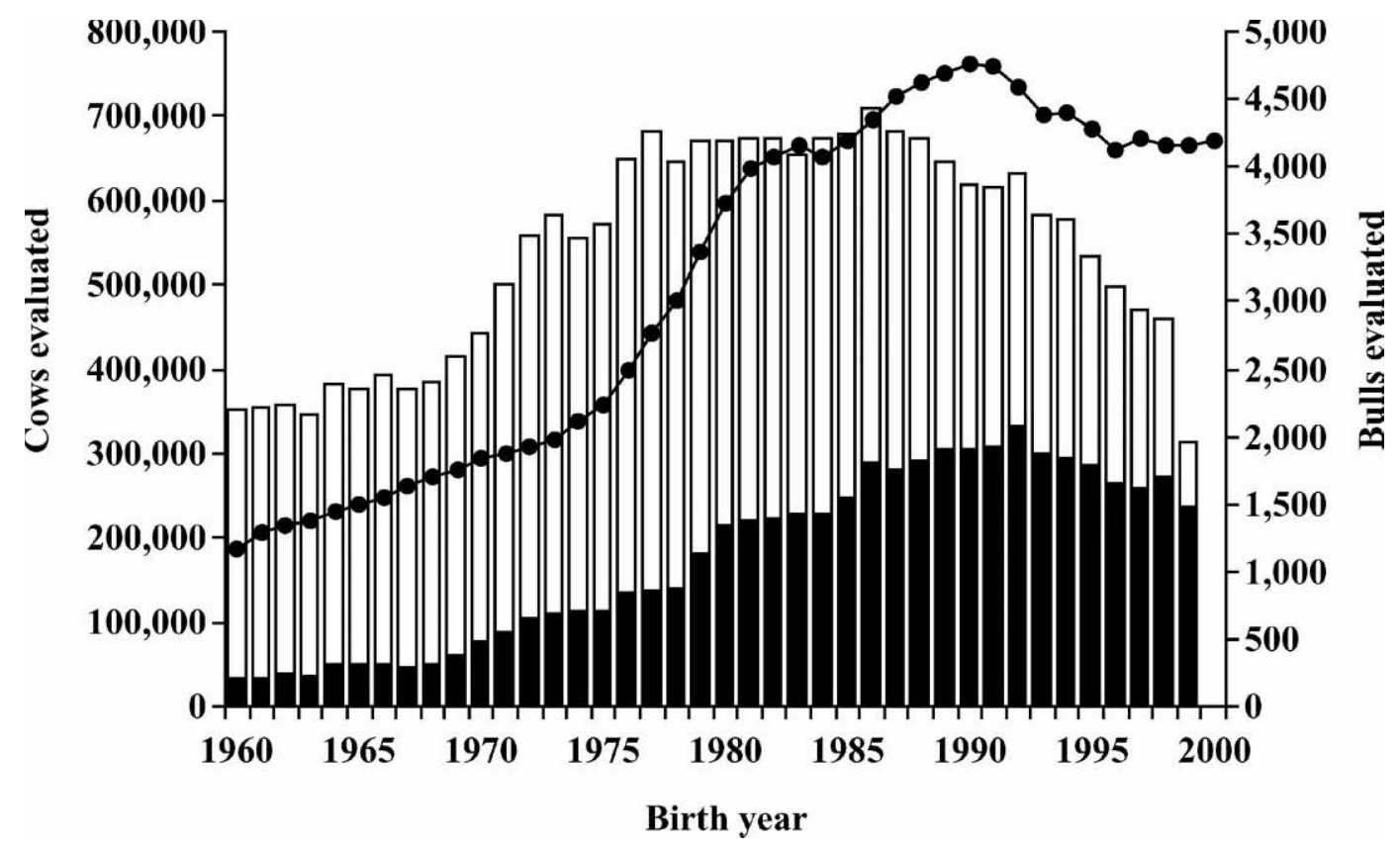

Figure 2. Numbers of evaluated cows ( ), and numbers of bulls with ( $\square$ ) and without ( $\square$ ) assigned National Association of Animal Breeders codes, by birth years.

in general, the countries reporting relative breeding values (RBV), change the base group for their evaluations annually. At the time of the US base change in January 1995, new factors to adjust for age and season were introduced, which incorporated adjustment for parity differences within age as well. To automatically account for changes in appropriate factors, and to provide information on the need to reestimate factors, ageparity effects by time periods were added to the AM equation. The preadjustments are multiplicative and consider each month of age. The AM effects are additive and group months within parity. Thus, both multiplicative (preadjustment) and additive (in the model) approaches are considered, with the primary advantage of inclusion of age-parity in the model being that it automatically considers changes over time.

From mid-1980 through 1998, adjustments for length of lactation were by projecting yield to $305 \mathrm{~d}$. Beginning in 1983, projection to $305 \mathrm{~d}$ was applied to all lactations, even those with a termination code indicating they had ceased milking. This was the result of research that demonstrated improvement in heritability and repeatability of records when projecting all shorter records. Based on the genetic merit of cows at that time, the logic was that few cows really quit giving milk; rather, the farmer chose to stop taking the milk. Most of the cows dried off before $305 \mathrm{~d}$ had very short calving intervals that would not have permitted a dry period of typical length. The projection for the remaining period to $305 \mathrm{~d}$ was based on the last test-day yield. For the few cows that did go dry on their own, the level of production on the last test day was low and thus relatively little extra credit was given. The projection of records is an important consideration in all evaluation models, not only the method of projection, but in inclusion of all records to avoid bias, and the proper weighting of records to account for the reduction in information. Projection to $305 \mathrm{~d}$ for cows dried off was mildly controversial when implemented. It is interesting to note, however, that the typical TDM application also included the underlying assumption that all cows continue milking through $305 \mathrm{~d}$. To characterize records as less than $305 \mathrm{~d}$ would require inclusion of a zero for yield for each herd test day that the cow was not milked, through $305 \mathrm{~d}$.

In 1999, the "Best Prediction" method was introduced in the United States in which each test-day yield is weighted by the DCR; thus accounting for correlations between yields on all possible DIM to estimate 305-d yield. Input to the animal model is still a lactation estimate, but all the individual test days are used for defining the 305-d lactation curve more precisely. This procedure has many of the benefits of the TDM.

Differences exist in the variability of within-herd yield and the genetic component of that variability (heritability). These differences were adjusted for in the United States beginning in 1991. Without this adjustment, a good bull with daughters in high-variance herds 
had an advantage over an equally good bull whose daughters were in low-variance herds. In addition to the adjustment to the size of deviation records, there is an adjustment to the weight the record receives in the AM calculations. The greater weighting for a record from a high-variance herd is in recognition of its higher heritability. Because these are counteracting adjustments, the impact is small for most animals.

Over a quarter of milk-recorded cows (27\%) are milked 3 times daily. The United States standardizes lactation yield to twice-daily milking, so adjustments reduce yields in which more frequent milking is practiced. Obtaining those adjustment factors with a high degree of confidence is one of the greater challenges in dairy cattle breeding. It is essentially impossible to obtain differences in yield solely due to milking frequency. The factors implemented in 1999 showed a smaller increase due to more frequent milking than had been assumed previously. Even though milking frequency factors will not fit each herd perfectly, cows within a herd are adjusted by the same set of factors and thus differences between cows in a comparison group are relatively unaffected. The greatest concern is for those herds that do not use the same management practices for all of their cows.

\section{DATA EXCHANGE AND DISTRIBUTION}

In the early 1980 s, genetic evaluations were distributed by postal and other delivery services. Over 5,000 bull owners received genetic evaluations by mail with a list of contributing daughters for their bulls. Scores of computer tapes with bull and cow evaluations were sent to DRPC, AI companies, and breed associations. Recipients often opted to receive these results by overnight delivery at their own expense. Ensuring the equitable distribution of information was a high priority, but delivery schedules and time zone differences occasionally resulted in difficulties. Beginning in 1993, an FTP server (i.e., a computer permanently connected to the Internet, with files available using the File Transfer Protocol) was used for the transfer of data, and in 1997, genetic evaluations were made available via the AIPL Internet site (http://aipl.arsusda.gov). All paper and magnetic media distribution was discontinued or phased out as industry cooperators developed systems to exploit the direct download of evaluation data. Providing the evaluation files in an encrypted format for advance download, and then providing the password for decryption at the scheduled release time, gave everyone access to evaluations at the same time, regardless of time zone and not depending on disparities of mail or parcel service. The Internet also provided the public with direct access to evaluations and other information through online queries. Between 1997 and 2005, many small improvements have been made to the data exchange system, taking advantage of improvements in computers, and the rapid development of Internet connectivity.

Also in 1997, evaluation frequency in the United States and Canada changed to 4 times per year, joining France, Germany, Great Britain, Italy, and The Netherlands. This change followed a 1993 symposium on continuous evaluation of dairy cattle and was not universally welcomed as it reduced the shelf life of promotional materials. Regardless, the best decisions are possible with the most current information. The increased frequency and reduced processing time, which together delivered evaluations $11 \mathrm{wk}$ earlier in the United States, were shown to be valued at over $\$ 60$ million annually. The semiannual evaluations had been in January and July. Quarterly evaluations are released in February, May, August, and November. Interbull had been providing its evaluation service in February and August and, with the November 1998 run, moved to quarterly evaluations as well.

Status of the Interbull evaluations has evolved over the years and gradually increasing use has been made of the information. In the beginning, the Interbull evaluation was given official status in the United States only if there was no USDA evaluation for a bull. In 1997, the Interbull evaluation was used instead of the USDA domestic evaluation when its reliability (REL) was 5\% higher than the USDA REL, which was less than $80 \%$. In 1998, Interbull evaluations were designated official if the REL of the USDA evaluation was less than $85 \%$, and the Interbull evaluation included more daughters and had a REL at least as high as the USDA evaluation. In 2001, the Interbull evaluations became official if they included daughter data from an additional country or if the Interbull evaluation excluded US data but had a higher REL. Although conceived to support the globalization of dairy genetics, Interbull evaluations were not generally welcomed by semen exporters. The MACE process, by including genetic correlations less than 1.0 , generally reduced variation (spread) in the estimated merit of bulls on the country scales of importers. This frustrated exporters because research had shown that the inclusion of estimated genetic correlations does not improve the prediction of future evaluations over the assumption of nearunity (0.995) correlations, although the 2 countries with the lowest correlations (Australia and New Zealand) were not examined until a study in late 2005. In that study, estimated genetic correlations had only a small impact on prediction of future national evaluations for most countries, but showed clear improvement for Australia and New Zealand. Moreover, MACE evaluations 
were not better predictors than the previous system of conversion equations for pairs of countries. Inherently, these conversion equations included the impact of nonunity genetic correlations in the resulting regression factors, although that fact was often not understood. Even if results are not superior to the previous method, Interbull evaluations do provide a means of deriving bull comparisons on all scales, thereby minimizing the resources that would otherwise be required in each country. Despite questions about the way data are combined, research has unanimously demonstrated that the inclusion of the additional daughters from other countries is beneficial.

Interchange of genetic material among countries has forced evaluation centers to accommodate the exchange of pedigree and genetic data. Interbull provides evaluations for bulls and also conversion equations that can be applied to cow evaluations so that genetic information on foreign dams can be incorporated into national systems.

\section{TRAITS OTHER THAN YIELD}

\section{Conformation}

All breeds converted their conformation scoring systems to linear type trait appraisals between 1980 and 1983. Conformation evaluations for all breeds were computed by the USDA from 1978 through 1982, depending on breed. Evaluations using all type scores were derived with a sire model having BLUP properties. Before that, bull evaluations were based on the average of daughters' latest score. In 1981, calculation of Holstein evaluations was transferred to the Holstein Association although the same evaluation model was used. Interbull expanded service to conformation evaluations for Holsteins in August 1999 and over the next $4 \mathrm{yr}$ expanded that to 4 other breeds. Relative to other nonyield traits, conformation, or type, has been scored and evaluated for a long time. As more has been learned about the relationship of individual type traits to profitability, emphasis among and within traits has shifted and even changed direction (e.g., for dairyness and body size). Changes have occurred in udder conformation over the last $25 \mathrm{yr}$ that make the cow more suitable to the high milk yield that has been achieved. Research has shown the value of the udder linear type traits in predicting herdlife or lifetime profitability. In general, these traits provided some improvement in the prediction, although most body traits were not helpful.

\section{Udder Health}

Data for SCS have been collected nationally since 1985. Genetic evaluations began in the United States in January 1994 and Interbull first initiated MACE SCS evaluations in May 2001. Most cows on test for yield are also tested for SCS (93\%), but 99\% of cows with records usable for yield evaluations and born in 2000 are also evaluated for SCS. In 1999, the Best Prediction procedure was applied to SCS test data in a similar fashion as for yield to arrive at an improved lactation value for the AM. Although the measured trait, somatic cells per milliliter, is the most consistent across countries (even milk yield is measured in both pounds and kilograms), transformations result in more than a dozen different trait definitions among Interbull populations. In the United States, SCS $=\log 2(\mathrm{SCC} /$ $100,000)+3$, and the sign is conserved; thus, higher PTA are undesirable. Before 2005, published PTA were computed (with a genetic base of zero) plus the breed mean for cows born in the base year. Beginning in 2005, mean PTA of base cows was set to 3.0 for all breeds, as was being done in Canada, replacing the inclusion of breed means in the published evaluations. This is more consistent with evaluations for other traits that are centered on the same number (zero) within all breeds, while maintaining evaluations in the anticipated range.

\section{Productive Life}

Evaluations for PL, the US genetic measure of longevity, began in January 1994 for bulls and in July 1995 for cows. The trait measures true longevity (capped at $84 \mathrm{mo}$ and including up to 10 mo per lactation), rather than functional longevity, which removes the influences from milk and component yields. In July 1994, the Holstein Association calculated an indirect evaluation of PL by genetic regression on type traits, which was combined with USDA evaluations in an approximate multitrait evaluation. Multitrait evaluations for all breeds were calculated by USDA beginning in August 2000 and included evaluations of milk, fat, and protein yields; SCS; and udder, feet and legs, and body size composites. Traits included were expanded in August 2003 to include daughter pregnancy rate (DPR), service-sire $\mathrm{CE}$, and daughter $\mathrm{CE}$. Multitrait evaluation of PL improved REL of evaluations by approximately $5 \%$ over the single-trait procedures. Modifications in November 2001 and February 2002 improved estimates for cows in herds that discontinued milk testing and cows that are embryo donors.

Other countries providing evaluations for true longevity are Australia, Israel, and New Zealand. The other countries participating in the Interbull longevity evaluations report functional longevity, and many of them use nonlinear survival analysis models. 
DPR

Genetic evaluations for DPR were introduced in February 2003. This is essentially an evaluation of days open (an increase of $1 \%$ DPR results in 4 fewer days open). Heritability for DPR is only $4 \%$, but a large phenotypic variance produces enough genetic variance to provide an opportunity for genetic progress. Emphasis on this trait has increased because of the detrimental effects that progress in yield has had on reproduction. The best information on days open (days not pregnant following calving) is from reported successful breeding dates supported by clinical pregnancy verification (reported pregnancy check) and subsequent calving. Various assumptions are made for other situations to maximize data and not introduce bias from using selected data. Beginning in November 2003, days open for recent records in progress were estimated based on current days open, age, lactation number, and CE score in the current lactation. Inclusion of these records improved REL for bull evaluations by more than $3 \%$.

\section{CE}

Evaluations for CE have been supported financially by the NAAB. From 1978 through 1998, calculations were done at Iowa State University by P. J. Berger. In 1999, the evaluations were moved to AIPL-USDA. Evaluation was by a sire threshold model until August 2002, when a sire-maternal grandsire threshold model was implemented. This provided for genetic evaluation of service sire calving ease (as previously) as well as for daughter calving ease. Only Holstein bulls were evaluated until 2005, at which time Brown Swiss bulls were included in a joint evaluation. Evaluation of Jerseys was not pursued, as few animals had calving difficulties and variation of the trait was small.

\section{Male Fertility}

Estimated relative conception rate (ERCR) is a phenotypic trait that provides an indication of bull fertility based on the 70-d first-service nonreturn rate of cows bred with their semen. Dairy Records Management Systems (DRMS, Raleigh, NC) calculated these ratings using breeding records from DRMS, AgSource, and MN DHIA and provide them free via their Web site (http:// www.drms.org/). The linear-model procedure was developed using results of the postdoctoral research of Roger McCraw (North Carolina State University, 1980). John Clay of DRMS directed the semiannual production of ERCR, additional research, and system improvements before and since its public release in 1986. Major changes were made in 1992 (inclusion of a cow effect and relationships), 1999 (substantial in- crease in the ratio of error to mating-bull variance), and 2000 (inclusion of bull $\times$ herd interaction and bull age effects, and improvement in data editing).

Beginning in 2003, breedings and pregnancy diagnoses from the AgriTech Analytics DRPC were used by Kent Weigel (University of Wisconsin) for a quarterly bull fertility summary. Data are primarily from Western herds, and the trait measured is conception (confirmed by pregnancy exam) for up to 5 breedings. A threshold model is used. Bull ratings are available free to AgriTech clients, or the list can be purchased.

\section{Interbull}

In addition to multicountry evaluations for milk, fat, protein, and conformation, Interbull extended the service to udder health in May 2001. As of November 2005, 24 national systems participated in SCS evaluation for at least one breed. A few countries (Denmark, Finland, Sweden) also produce an evaluation for clinical mastitis, and Norway participates in this evaluation but not SCS. Collection of clinical mastitis data is assisted in those countries by national regulations that require udder treatment to be administered by veterinarians. In the Interbull evaluations, SCS is used as an indicator trait for countries not supplying clinical mastitis national evaluations. Longevity evaluation was added for Holsteins in November 2004 and for other breeds in February 2005 with 13 national systems participating. Calving ease was also included for Holsteins in February 2005. Table 1 shows the expansion of the Interbull service across Holstein countries and traits.

\section{Indices}

In 1984, an economic index for a Cheddar cheese market (cheese-yield dollars) was added to the index for a general market (milk-fat dollars) initiated in 1971 and the milk-fat-protein dollars index instituted in 1976 to meet the needs of producers for different markets. The primary index was changed to Net Merit in 1994 by reducing the value by $30 \%$ to account for feed cost, and including SCS and PL as indicators for health or maintenance costs. Certain conformation traits (udder, feet and legs, size) were incorporated into the index in 2000 and the basis was changed from lactation to lifetime (3 times as large). In 2003, DPR and service sire and daughter $\mathrm{CE}$ evaluations were included in Net Merit, Cheese Merit, and Fluid Merit indices.

Most breed associations calculate indices that are similar to Net Merit, but generally put more weight on conformation. The Holstein Association provides a typeproduction index (TPI), the American Jersey Cattle Association provides a performance index (JPI), and other 
Table 1. Numbers of national Holstein populations ${ }^{1}$ participating in the Interbull evaluation service by trait group and year

\begin{tabular}{|c|c|c|c|c|c|c|}
\hline \multirow[b]{2}{*}{ Year } & \multicolumn{6}{|c|}{ Trait } \\
\hline & Yield & Conformation & $\begin{array}{l}\text { Udder } \\
\text { health }\end{array}$ & Longevity & $\begin{array}{l}\text { Calving } \\
\text { ease }\end{array}$ & $\begin{array}{l}\text { Female } \\
\text { fertility }\end{array}$ \\
\hline 1994 & 3 & & & & & \\
\hline 1995 & 9 & & & & & \\
\hline 1996 & 12 & & & & & \\
\hline 1997 & 19 & & & & & \\
\hline 1998 & 22 & & & & & \\
\hline 1999 & 26 & 10 & & & & \\
\hline 2000 & 26 & 14 & & & & \\
\hline 2001 & 27 & 19 & 13 & & & \\
\hline 2002 & $26^{2}$ & 20 & $14^{2}$ & & & \\
\hline 2003 & 26 & 22 & 17 & & & \\
\hline 2004 & 27 & 22 & 19 & 14 & & \\
\hline 2005 & 27 & $19^{3}$ & 24 & 18 & 12 & $11^{4}$ \\
\hline
\end{tabular}

${ }^{1}$ Red Holsteins are counted as separate populations in some countries (Denmark, France, Switzerland).

${ }^{2}$ Austrian and German data combined.

${ }^{3}$ Data of Denmark, Finland, and Sweden were combined.

${ }^{4}$ Pilot run only.

breeds have similar production-type indices. More historical information on the selection indices provided is in the companion article in this issue by George Shook.

\section{LOOKING AHEAD}

Considerable effort and expense have been directed toward mapping the bovine genome. Markers have been useful in testing for some deleterious genes, but benefits from identifying genes and markers for currently evaluated traits lie largely in the future. Relating maps to traits is a formidable challenge and there are probably proprietary advances that, by their nature, are not known or used by the industry at large. Presently, AI companies are likely using DNA test results to select from among full brothers for conventional progeny testing but efforts may be less effective than predicted. Marker-assisted selection may augment, but seems unlikely to replace, progeny testing in the future. Verification or determination of parentage through DNA tests could increase the accuracy of genetic evaluations markedly, but depend on convenient, inexpensive procedures. Such testing may have been first done on a large scale in New Zealand, but has been scaled back to check only daughters of bulls graduating from progeny test and where there is cause for question (re-insemination at short intervals with semen from different bulls or if also exposed to a herd bull). A similar program is operating for Alta Genetics, Inc., in which there is DNA verification for daughters of graduate bulls and for herds before joining their cooperator-herd program.

Cloning could assure the availability of particular genotypes or multiply the impact of particular cows, but is not practicable if products are not approved by the FDA or corresponding bodies in other countries. Unless the costs of these techniques are lowered, they are unlikely to play a major role in genetic programs. After an initial flurry of activity, the numbers of animals resulting from embryo splitting and nuclear transfer have declined.

Mandatory animal identification in North America follows corresponding requirements in other countries. Impact on genetic evaluation programs must be tempered with the realization that although unique animal identification is essential, it is of little value in this context without linkage to parents (i.e., pedigree information). Merely knowing who an animal is will not be of benefit.

With improved genetic ability of cows and use of bovine somatotropin, the traditional lactation length of $305 \mathrm{~d}$ may no longer be optimal; typical lactation length has increased over time. As distressing as it may be to marketers, genetic evaluations may become even more frequent, although official releases may be limited to 3 or 4 annually with additional interim information provided that is nearly as accurate, but not official. Use of customized selection indices and routine consideration of inbreeding will likely increase as logical components of increased application of computers to dairy farm management. Emphasis will continue to increase for health and fitness traits, but progress will be slow unless the current challenges of limited data and lack of uniformity are addressed. Only when data currently recorded are readily available for research can those traits be discovered that provide the best genetic opportunities for improving cow health and longevity. Some producers have expressed concern about public access to health data if provided to a national database at 
USDA. Interest in crossbreeding as a means of improving genetic fitness of cows has been increasing and genetic evaluation systems of the future will need to include crossbred animals. This has already occurred in some countries and was an effective improvement, especially where crossbred cows constitute a high percentage of the population.

Predictions regarding industry directions are safer than those regarding organizations. The global dairy industry is accustomed to the service of international evaluations and that will continue, likely in the form of Interbull, although there are detractors. As is the situation with national evaluations, international evaluations are undergoing refinement. Improvements may be modest at best, and major changes will be in the expansion of traits.

\section{CONCLUSIONS}

We may be past the time when there will be revolutionary changes in genetic evaluation techniques. Improvements may be perceived as major in a relative sense at the time, but minor compared with many changes in the past half-century. Changes will likely be incremental, each addressing some shortcoming of the prior system, improving evaluations of only a few animals significantly or a large number of animals to a lesser degree.

Over time, additions to knowledge and increased capacity for computing have made data acquisition, processing, and distribution possible at new and improved levels. Expanded processing capacity is one reason for the growing array of traits, generally having lower heritability, which are evaluated. These health and fitness traits are of interest because the emphasis and selection for yield has been successful to the point that these other traits are seen as limiting factors, due to a negative relationship with yield, or because of their high relative economic costs. The traits added recently have been those with a positive influence on animal health and well being.

This quarter-century began with heavy emphasis on yield. Expansion to traits other than production occurred not only because it was possible but also because it was increasingly recognized that profitable cows are determined by absence of limiting characteristics as much or more than superiority in certain traits. Economic indices have incorporated the added information and have evolved to represent lifetime profitability more closely. Emphasis on genetic relationships among animals has increased, as inbreeding has been a growing concern. Evaluation systems, mating programs, and interest in crossbreeding have been affected by this change. Genetic sourcing has become increasingly in- ternational, and international evaluations for bulls and incorporation of foreign data into domestic cow evaluation systems is beneficial and now commonly accepted.

This review is not all-inclusive but the main advances in genetic evaluation techniques have been mentioned. Present models, computing strategies, data management, information distribution, and international services developed in recent years place the dairy industry in an excellent position to progress in the face of presently unknown challenges. The genetic progress made in the last $25 \mathrm{yr}$ has been the result of cooperation among AIPL, university researchers, and various industry organizations; and continued cooperation is perhaps the greatest challenge in achieving another $25 \mathrm{yr}$ of success.

\section{ACKNOWLEDGMENTS}

Contributions of ideas and review by John Clay, George Wiggans, Paul VanRaden, Melvin Kuhn, John Cole, and especially Ashley Sanders are gratefully acknowledged.

\section{REFERENCES}

Banos, G., G. R. Wiggans, and R. L. Powell. 2001. Impact of paternity errors in cow identification on genetic evaluations and international comparisons. J. Dairy Sci. 84:2523-2529.

Berger, P. J. 1994. Genetic prediction for calving ease in the United States: Data, models, and use by the dairy industry. J. Dairy Sci. 77:1146-1153.

Cassell, B. G., B. T. McDaniel, and H. D. Norman. 1983. Modified contemporary comparison sire evaluations from first, all, and later lactations. J. Dairy Sci. 66:140-147.

Dickinson, F. N., H. D. Norman, R. L. Powell, L. G. Waite, B. T. McDaniel, and US Dept. of Agriculture. 1976. Procedures used to calculate the USDA-DHIA Modified Contemporary Comparison. USDA-ARS Prod. Res. Rep. 165:18-34.

Djemali, M., P. J. Berger, and A. E. Freeman. 1987. Ordered categorical sire evaluation for dystocia in Holsteins. J. Dairy Sci. 70:2374-2384.

Ducrocq, V., and B. Besbes. 1993. Solution of multiple trait animal models with missing data on some traits. J. Anim. Breed. Genet. 110:81-92.

Everett, R. W., inventor. 1994. Method of bovine herd management. Cornell Research Foundation, assignee. US Pat. No. 5,351,644.

Gianola, D., and R. L. Fernando. 1986. Bayesian methods in animal breeding theory. J. Anim. Sci. 63:217-244.

Gianola, D., and J. L. Foulley. 1983. Sire evaluation for ordered categorical data with a threshold model. Genet. Sel. Evol. 15:201-224.

Hazel, L. N., G. E. Dickerson, and A. E. Freeman. 1994. The selection index - then, now, and for the future. J. Dairy Sci. 77:3236-3251.

Henderson, C. R. 1974. General flexibility of linear model techniques for sire evaluation. J. Dairy Sci. 57:963-972.

INTERBULL. 1992. Sire evaluation procedures for dairy production traits practised in various countries. Bull. No. 5, International Bull Evaluation Service, Uppsala, Sweden.

Jones, L. P., and M. E. Goddard. 1990. Five years experience with the animal model for dairy evaluations in Australia. Proc. 4th World Congr. Genet. Appl. Livest. Prod., Edinburgh, Scotland XIII:382-385.

Kirkpatrick, M., W. G. Hill, and R. Thompson. 1994. Estimating the covariance structure of traits during growth and ageing, illustrated with lactation in dairy cattle. Genet. Res. 64:57-69. 
Kuhn, M. T., P. M. VanRaden, and J. L. Hutchison. 2004. Use of early lactation days open records for genetic evaluation of cow fertility. J. Dairy Sci. 87:2277-2284.

Meuwissen, T. H. E., G. de Jong, and B. Engel. 1996. Joint estimation of breeding values and heterogeneous variances of large data files. J. Dairy Sci. 79:310-316.

Meuwissen, T. H., and Z. Luo. 1992. Computing inbreeding coefficients in large populations. Genet. Sel. Evol. 24:305-313.

Misztal, I., T. J. Lawlor, and T. H. Short. 1993. Implementation of single- and multiple-trait animal models for genetic evaluation of Holstein type traits. J. Dairy Sci. 76:1421-1432.

Nieuwhof, G. J., H. D. Norman, and F. N. Dickinson. 1989. Phenotypic trends in herdlife of dairy cows in the United States. J. Dairy Sci. 72:726-736.

Nieuwhof, G. J., R. L. Powell, and H. D. Norman. 1989. Ages at calving and calving intervals for dairy cattle in the United States. J. Dairy Sci. 72:685-692.

Norman, H. D., F. N. Dickinson, and J. R. Wright. 1985. Merit of extending completed records of less than 305 days. J. Dairy Sci. 68:2646-2654.

Norman, H. D., T. J. Lawlor, J. R. Wright, and R. L. Powell. 2004. Performance of Holstein clones in the United States. J. Dairy Sci. 87:729-738.

Norman, H. D., R. L. Powell, and F. N. Dickinson. 1976. Modified contemporary and herdmate comparisons in sire summary. J. Dairy Sci. 59:2155-2161.

Norman, H. D., R. L. Powell, and G. R. Wiggans. 1991. Comparison of genetic evaluations from animal model and modified contemporary comparison. J. Dairy Sci. 74:2309-2316.

Norman, H. D., R. L. Powell, and J. R. Wright. 1987. Influence of genetic differences in merit of mates on sire evaluation. J. Dairy Sci. 70:141-157.

Norman, H. D., R. L. Powell, J. R. Wright, and R. E. Pearson. 1996. Phenotypic relationship of yield and type scores from first lactation with herd life and profitability. J. Dairy Sci. 79:689-701.

Norman, H. D., R. L. Powell, J. R. Wright, and C. G. Sattler. 2001. Overview of progeny-test programs of artificial-insemination organizations in the United States. J. Dairy Sci. 84:1899-1912.

Norman, H. D., R. L. Powell, J. R. Wright, and C. G. Sattler. 2003. Timeliness and effectiveness of progeny testing through artificial insemination. J. Dairy Sci. 86:1513-1525.

Norman, H. D., P. M. VanRaden, J. R. Wright, and J. S. Clay. 1999. Comparison of test interval and best prediction methods for estimation of lactation yield from monthly, a.m.-p.m., and trimonthly testing. J. Dairy Sci. 82:438-444.

Norman, H. D., P. M. VanRaden, J. R. Wright, and L. A. Smith. 1999. Mathematical representations of correlations among yield traits and somatic cell score on test day. J. Dairy Sci. 82:2205-2211.

Norman, H. D., L. G. Waite, G. R. Wiggans, and L. M. Walton. 1994. Improving accuracy of the United States genetics database with a new editing system for dairy records. J. Dairy Sci. 77:3198-3208.

Powell, R. L. 1978. A procedure for including the dam and maternal grandsire in USDA DHIA cow indexes. J. Dairy Sci. 61:794-800.

Powell, R. L., and H. D. Norman. 1986. Genetic and environmental differences between registered and grade Holstein cows. J. Dairy Sci. 69:2897-2907.

Powell, R. L., and H. D. Norman. 1998. Use of multinational data to improve national evaluations of Holstein bulls. J. Dairy Sci. 81:2257-2263.

Powell, R. L., and H. D. Norman. 1999. Examination of more frequent genetic evaluations for dairy bulls. J. Dairy Sci. 82:2766-2770.

Powell, R. L., and H. D. Norman. 2000. Impact of genetic correlations on accuracy of predicting future evaluations. J. Dairy Sci. 83:1552. Online. Available: http://jds.fass.org/.

Powell, R. L., H. D. Norman, and G. Banos. 2000. Improving prediction of national evaluations by use of data from other countries. J. Dairy Sci. 83:368. Online. Available: http://jds.fass.org/

Powell, R. L., H. D. Norman, F. N. Dickinson, and US Dept. of Agriculture. 1976. The USDA-DHIA Modified Contemporary Comparison cow index. USDA-ARS Prod. Res. Rep. 35-40.
Powell, R. L., H. D. Norman, and R. M. Elliott. 1981. Different lactations for estimating genetic merit of dairy cows. J. Dairy Sci. 64:321-330

Powell, R. L., H. D. Norman, and R. M. Elliott. 1981. Accuracy of genetic indexes of cows from adding relatives. J. Dairy Sci. 64:838-843.

Powell, R. L., H. D. Norman, and A. H. Sanders. 2003. Progeny testing and selection intensity for Holstein bulls in different countries. J. Dairy Sci. 86:3386-3393.

Powell, R. L., A. H. Sanders, and H. D. Norman. 2004. Accuracy of foreign dairy bull evaluations in predicting United States evaluations for yield. J. Dairy Sci. 87:2621-2626.

Powell, R. L., A. H. Sanders, and H. D. Norman. 2005. Impact of genetic correlations on international evaluations to predict milk traits. J. Dairy Sci. 88:3679-3687.

Powell, R. L., and P. M. VanRaden. 2002. International dairy bull evaluations expressed on national, subglobal, and global scales. J. Dairy Sci. 85:1863-1868.

Ptak, E., and L. R. Schaeffer. 1993. Use of test day yields for genetic evaluation of dairy sires and cows. Livest. Prod. Sci. 34:23-34.

Quaas, R. L., and E. J. Pollak. 1981. Modified equations for sire models with groups. J. Dairy Sci. 64:1868-1872.

Schaeffer, L. R. 1994. Multiple-country comparison of dairy sires. J. Dairy Sci. 77:2671-2678.

Schaeffer, L. R., and J. C. M. Dekkers. 1994. Random regression in animal models for test-day production in dairy cattle. Proc. 5th World Congr. Genet. Appl. Livest. Prod., Guelph, ON, Canada 18:443-446.

Schaeffer, L. R., and B. W. Kennedy. 1986. Computing strategies for solving mixed model equations. J. Dairy Sci. 69:575-579.

Schutz, M. M. 1994. Genetic evaluation of somatic cell scores for United States dairy cattle. J. Dairy Sci. 77:2113-2129.

Schutz, M. M., P. M. VanRaden, and G. R. Wiggans. 1994. Genetic variation in lactation means of somatic cell scores for six breeds of dairy cattle. J. Dairy Sci. 77:284-293.

Schutz, M. M., P. M. VanRaden, G. R. Wiggans, and H. D. Norman. 1995. Standardization of lactation means of somatic cell scores for calculation of genetic evaluations. J. Dairy Sci. 78:1843-1854.

Swalve, H. H. 1995. Test day models in the analysis of dairy production data-A review. Arch. Anim. Breed. 38:591-612.

van der Werf, J. H., M. E. Goddard, and K. Meyer. 1998. The use of covariance functions and random regressions for genetic evaluation of milk production based on test day records. J. Dairy Sci. 81:3300-3308.

Van Tassell, C. P., G. R. Wiggans, and I. Misztal. 2003. Implementation of a sire-maternal grandsire model for evaluation of calving ease in the United States. J. Dairy Sci. 86:3366-3373.

Van Tassell, C. P., G. R. Wiggans, and H. D. Norman. 1999. Method $\mathrm{R}$ estimates of heritability for milk, fat, and protein yields of United States dairy cattle. J. Dairy Sci. 82:2231-2237.

VanRaden, P. M. 1990. Potential improvements in animal model evaluation systems. Proc. 4th World Congr. Genet. Appl. Livest. Prod., Edinburgh, Scotland XIII:357-363.

VanRaden, P. M. 1992. Accounting for inbreeding and crossbreeding in genetic evaluation of large populations. J. Dairy Sci. 75:3136-3144.

VanRaden, P. M. 1997. Lactation yields and accuracies computed from test day yields and (co)variances by best prediction. J. Dairy Sci. 80:3015-3022.

VanRaden, P. M. 2001. Methods to combine estimated breeding values obtained from separate sources. J. Dairy Sci. 84(E. Suppl.):E47-E55

VanRaden, P. M., and E. J. H. Klaaskate. 1993. Genetic evaluation of length of productive life including predicted longevity of live cows. J. Dairy Sci. 76:2758-2764.

VanRaden, P. M., and A. H. Sanders. 2003. Economic merit of crossbred and purebred US dairy cattle. J. Dairy Sci. 86:1036-1044.

VanRaden, P. M., A. H. Sanders, M. E. Tooker, R. H. Miller, H. D. Norman, M. T. Kuhn, and G. R. Wiggans. 2004. Development of a national genetic evaluation for cow fertility. J. Dairy Sci. $87: 2285-2292$. 
VanRaden, P. M., and A. J. Seykora. 2003. Net Merit as a measure of lifetime profit: 2003 revision. AIPL Res. Rpt. NM\$2. USDA, Beltsville, MD.

VanRaden, P. M., and L. A. Smith. 1999. Selection and mating considering expected inbreeding of future progeny. J. Dairy Sci. 82:2771-2778.

VanRaden, P. M., and G. R. Wiggans. 1991. Derivation, calculation, and use of national animal model information. J. Dairy Sci. 74:2737-2746.

VanRaden, P. M., and G. R. Wiggans. 1995. Productive life evaluations: Calculation, accuracy, and economic value. J. Dairy Sci. 78:631-638.

VanRaden, P. M., G. R. Wiggans, and C. A. Ernst. 1991. Expansion of projected lactation yield to stabilize genetic variance. J. Dairy Sci. 74:4344-4349.

Weigel, K. A., T. J. J. Lawlor, P. M. VanRaden, and G. R. Wiggans. 1998. Use of linear type and production data to supplement early predicted transmitting abilities for productive life. J. Dairy Sci. 81:2040-2044.

White, J. M., W. E. Vinson, and R. E. Pearson. 1981. Dairy cattle improvement and genetics. J. Dairy Sci. 64:1305-1317.

Wiggans, G. R., N. Gengler, and J. R. Wright. 2004. Type trait (co)variance components for five dairy breeds. J. Dairy Sci. 87:2324-2330.
Wiggans, G. R., and M. E. Goddard. 1997. A computationally feasible test day model for genetic evaluation of yield traits in the United States. J. Dairy Sci. 80:1795-1800.

Wiggans, G. R., I. Misztal, and C. P. Van Tassell. 2003. Calving ease (co)variance components for a sire-maternal grandsire threshold model. J. Dairy Sci. 86:1845-1848.

Wiggans, G. R., I. Misztal, and L. D. Van Vleck. 1988. Implementation of an animal model for genetic evaluation of dairy cattle in the United States. J. Dairy Sci. 71(Supp 2):54-69.

Wiggins, G. R. and P. M. VanRaden. 1991. Method and effect of adjustment for heterogeneous variance. J. Dairy Sci. 74:43504357.

Wiggans, G. R., and P. M. VanRaden. 1993. Flow of information for genetic evaluation of yield traits. Pages 19-28 in Proc. Symp. Continuous Eval. Dairy Cattle, College Park, MD. University of Illinois, Urbana.

Wiggans, G. R., P. M. VanRaden, and J. Zuurbier. 1995. Calculation and use of inbreeding coefficients for genetic evaluation of United States dairy cattle. J. Dairy Sci. 78:1584-1590.

Zarnecki, A., J. Jamrozik, and H. D. Norman. 1991. Comparison of ten Friesian strains in Poland for yield traits from first three parities. J. Dairy Sci. 74:2303-2308.

Zarnecki, A., H. D. Norman, and J. Jamrozik. 1990. Lifetime performance of ten Friesian strains in Poland. Proc. 4th World Congr. Genet. Appl. Livest. Prod., Edinburgh, Scotland XIV:70-73. 